\title{
An Empirical Study of Intercultural Communicative Competence: A Case Study of Hospitality Higher Education in China
}

\author{
Huijun Yang, Reggie Kwan, Philips Wang, Steven Ng \\ Hong Kong Caritas Institute of Higher Education, Tseung Kwan O, Hong Kong
}

\begin{abstract}
The study aims to explore the stakeholders' perception towards intercultural communicative competence (ICC) in hospitality higher education and examine what ICCs are important to graduates in their career development. In-depth interview and content analysis are adopted and 10 ICC items are found to represent ICC in hotel schools in China. In order to investigate what ICCs are important to graduates in their career development, descriptive statistics and one-way analysis of variance (ANOVA) with a post-hoc Scheffe test were conducted. Discussion and recommendations are provided to hospitality undergraduates, educators, and employers in China. From graduates' perspective, the study may help them improve their ICC learning at schools for better advancement in their future careers. From educators' perspective, it may provide a better understanding from the stakeholders' perceptions when integrating cultural elements with communicative competence in hospitality education, and prepare qualified students. From employers' perspective, ICC can be a valuable tool when recruiting quality graduates. A greater understanding of ICC contributes to graduates' career development, universities' curriculum validation, and service quality in hospitality industry.
\end{abstract}

Keywords: intercultural communicative competence (ICC), hospitality higher education, career development, China

\section{Introduction}

According to United Nations World Tourism Organization (UNWTO, 2008), China will be the most popular tourist destination by 2020 . Nowadays, international hotel chains which have aggressively expanded their operations into China include InterContinental Hotels, Marriott International, Accor, Starwood Hotels and Resorts, Best Western International, Hilton International, and Hyatt Corporation (Aliouche \& Schlentrich, 2011). This rapid expansion of the international hospitality in China has increased opportunities for intercultural communication. Intercultural communication is often defined as communication between people

Huijun Yang, assistant professor, School of Business and Hospitality Management, Hong Kong Caritas Institute of Higher Education.

Reggie Kwan, professor, president, Hong Kong Caritas Institute of Higher Education.

Philips Wang, professor, vice president, Hong Kong Caritas Institute of Higher Education.

Steven $\mathrm{Ng}$, associate professor, School of Business and Hospitality Management, Hong Kong Caritas Institute of Higher Education.

Correspondence concerning this article should be addressed to Huijun Yang, School of Business and Hospitality Management, Hong Kong Caritas Institute of Higher Education, 18 Chui Ling Road, Tseung Kwan O, New Territories, Hong Kong. Email: juneyanghuijun@gmail.com. Tel.: 852-3653 6626. 
from different national cultures (Gudykunst \& Mody, 2002). China's emergence as a major regional and global source market for tourism is creating opportunities for college graduates to work in hospitality industry. With this trend developing, there is an increasing demand in the industry for professionals who are able to mediate among different cultures. The expansion of hospitality industry provides multinational and multicultural scenarios for hospitality professionals. In order to communicate effectively with people from different cultural backgrounds, one should first learn to "interpret" dissimilar mentalities, respect the other people's perceptions of the world, and accept others as they are. That could be regarded as the core of intercultural communicative competence (ICC). Lustig and Koester (2006) defined culture as "a learned set of shared interpretations about beliefs, values, norms, and social practices, which affect the behaviors of a relatively large group of people". Intercultural communication generally involves face-to-face communication between people from different national cultures (Gudykunst \& Mody, 2002). Since national cultures are involved, communicative competence in one or more foreign languages is a vital part of the integration. A foreign language curriculum for hospitality students will have to integrate language with culture by placing the emphasis on cultural understanding rather than on the mechanical mastery of language skills for narrow instrumental, functional purposes (Whyte, 1990).

The Educational Ministry of China issued "The Basic Requirement of College English Curriculum Teaching" (Educational Ministry of China, 2004), which mentioned that cultural knowledge should be incorporated into English language teaching. Although there was a small component of intercultural communication in the curriculum, the majority of the curriculum focused on the improvement of macro-skills, such as speaking, listening, reading, writing, and translating. Furthermore, the College English Test (CET), a competence test of English for non-majors of English language in China's tertiary education, aims at improving the students' comprehensive competency in applying English, especially listening and speaking, so that they will be able to effectively exchange oral and written information in future work and social communication (National CET IV and VI Committee, 2007). Judging from the sentential context, "social communication" does not necessarily imply "cultural communication" or even "intercultural communication"; instead, it seems to be more related to "linguistic competence" or "communicative competence" without much emphasis on the development of ICC. Collier (1989) identified that ICC includes four different approaches, namely, ethnography of speaking, cross-cultural attitudes, behavioral skills, and cultural identity. Therefore, it would be even better if communicative competence could be integrated with intercultural competence to cultivate ICC, particularly in hospitality higher education institutions.

The primary objectives of this study are to:

(1) Explore the stakeholders' perceptions towards ICC in hospitality higher education;

(2) Examine what ICCs are important to graduates in their career development.

\section{Literature Review}

ICC provides an opportunity for the individual to develop an awareness of cultural dynamics and to discern multiple identities in order to maintain a state of multicultural coexistence (Chen \& Starosta, 1996). Cultural sensitivity is the core element of ICC (Chen \& Starosta, 1996). In a real teaching scenario, some educators might still believe that it would not be so necessary to emphasize the importance of intercultural competence. Or they might find it easier to focus on repeated drills or to correct the linguistic mistakes. Sometimes, cultural content was often stripped from learning materials (Corbett, 2003). ICC involves disciplines of linguistics, ethnography, history, psychology, and others in teaching cultures. A culture has two 
dimensions: open and hidden (Gu, 2000). The word "hidden" indicates a degree of difficulty to teach and learn in practice. Obvious linguistic symbols of alphabet, words, and grammar rules are relatively easy for the learners to observe and learn. But the intangible aspect might pose as a challenge for the educators to handle in the classroom. Increased intercultural understanding and improved intercultural communication have become increasingly important to the world of blending cultures, experience, and business practices (Saee, 2006). Interculturally, competent persons must know how to negotiate and respect the meanings of cultural symbols and norms that are changing during their interactions (Kim, 1994). Ferraro (2006) indicated that ICC is important in hospitality and travel companies which have failed to train front-line employees with ICC. ICC training and education have to provide front-line workers with a way to improve their service encounters with foreign customers (Kotler, Bowen, \& Makens, 2003). Weiler and Ham (2001) stated that tour guides must have a solid grasp of the culture they interpret as well as the culture their clients bring with them. Cultural misunderstanding may be avoided or reconciled more easily by tour guides who have intercultural understanding and the ability to communicate effectively between cultures (Gurung, Simmons, \& Devlin, 1996). Due to its difficult nature and extensive applicability nowadays, the intercultural misunderstanding and cross-cultural difficulties have been examined by many researchers (Holliday, Hyde, \& Kullman, 2004; Lustig \& Koester, 2006; R. Scollon \& S. W. Scollon, 2001). If a hospitality or travel firm does not perform to the expectations of the international guest, a cross-cultural conflict may occur. These conflicts are often caused by cultural norms and values that are dissimilar between guests and service workers and can lead to a dissatisfied customer, a frustrated service provider, and lost business (Cushner \& Brislin, 1996).

To avoid misinterpretation of other cultures while promoting one's own culture and to achieve effective communication, the graduates in hospitality industry need to be able to mediate between or among distinct cultures. Language educators agree that traditional language teaching has generally concentrated on the skills of speaking, listening, reading, and writing (Corbett, 2003). However, the ultimate goal of an intercultural approach to language education is not so much "native speaker competence" but rather an "ICC". Le Roux (2002) emphasized that effective educators are culturally competent in cross-cultural encounters in a multi-cultural classroom. Deardorff (2006) identified that intercultural competences should be included in teaching objectives at institutions of higher education and he also has developed a measurement of intercultural competence. Based on Deardorff's (2006) model, Tian (2013) investigated the components of intercultural competence for English language learners in China. To achieve ICC, a graduate has to understand both the language and culture of the target country and serve as a diplomat or a bridge between the "home" community and the "target" community (Corbett, 2003). In order to educate students to be aware of the cultural differences in university settings, the ICC should be added into the hospitality curriculum.

In China, many studies have been found to investigate the ICC. Some studies aim to explore Chinese students' intercultural experiences and their social and academic challenges in adapting to an educational system (Gu, 2009; Gu \& Maley, 2008; Liu, 2000). Some researchers suggest that ICC should be the ultimate goal of cultural teaching in foreign language education and some teaching pedagogies have been proposed for this purpose (Chen, 2001; Hu \& Gao, 1997; Wang, 1999). The goal of cultural teaching has been expanded to include promoting the acquisition of cultural knowledge, awareness, and understanding (A. D. Zhang \& X. Zhang, 2002). However, few studies are found to identify ICC from stakeholders' perceptions in the hospitality higher education. Additionally, studies on what ICCs are important to graduates in their career development are even fewer. 


\section{Methodology}

In-depth interview and content analysis were adopted to explore the stakeholders' perceptions towards ICC in hospitality higher education (Objective 1). In order to investigate what ICCs are important to graduates in their career development, descriptive statistics and one-way analysis of variance (ANOVA) with a post-hoc Scheffe test were conducted (Objective 2). In-depth interviews based on open-ended questions are conducted with stakeholders, they are: hospitality educators, graduates, and employers in China. For the selection of the interviewees, purposive sampling was employed. Purposive sampling is best used with small numbers of individuals who may well be sufficient for understanding human perceptions, which are the main justification for a qualitative audience research (Patton, 1990). The interviewees are considered to be most informed and knowledgeable of the issues and problems besetting the ICC. Grounded on the relevant literature review (Deardorff, 2006; Tian, 2013), a total of 12 items were generated as the initial items to be used by the researchers during the in-depth interviews (see Table 1 (a)).

Table 1

ICC Items \begin{tabular}{|l|l|l|}
\hline $\begin{array}{l}\text { ICC based on relevant literature } \\
\text { review }\end{array}$ & $\begin{array}{l}\text { ICC generated from the in-depth } \\
\text { interviews }\end{array}$ & ICC based on the literature review and in-depth interviews \\
\hline
\end{tabular}

Scale items (a)

\begin{tabular}{|l|l|l|} 
Scale items (b) & Initial scale items (c) & Updated items (d)
\end{tabular}

\begin{tabular}{|l|l|l}
\hline 1. Understanding others' & $\begin{array}{l}\text { 1. Importance of ICC for } \\
\text { hospitality students in their Importance of ICC for } 1 \text {. Importance of ICC for }\end{array}$ \\
hospitality students in their hospitality students in their
\end{tabular}

worldviews

2. Culture-specific knowledge

and understanding host culture's 2 .

traditions career $^{*}$ career $^{*}$ career $^{*}$

3. Adaptability and adjustment to 3 . a new cultural environment

2. Language competency*

2. Language competency ${ }^{*}$ $\begin{aligned} & \text { 3. Understanding of other } \\ & \text { cultural values }\end{aligned} \begin{aligned} & 3 \text {. Understanding of and } \\ & \text { respect for other cultural Understanding of and }\end{aligned} \mid \begin{aligned} & \text { respect for other cultural } \\ & \text { resper }\end{aligned}$ values $\quad$ values

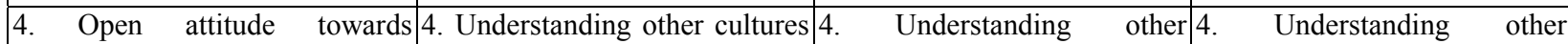
cross-cultural learning and to helps understand one's own cultures helps understand cultures helps understand \begin{tabular}{|l|l|l|l} 
people from other cultures & better & one's own better & one's own better \\
\hline 5. & $5 . \mathrm{L}$
\end{tabular}

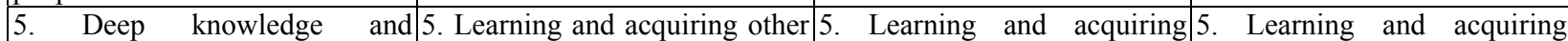
understanding of culture (one's cultural values threaten one's other cultural values threaten other cultural values threaten own and others') own identity ${ }^{*}$ one's own identity ${ }^{*}$ one's own identity ${ }^{*}$

\begin{tabular}{|c|c|c|c|}
\hline 6. Respect for other cultures & $\begin{array}{l}\text { 6. Cultural values are neither } \\
\text { right nor wrong, but just } \\
\text { different }\end{array}$ & $\begin{array}{l}\text { 6. Cultural values are neither } \\
\text { right nor wrong, but just } \\
\text { different }\end{array}$ & $\begin{array}{l}\text { 6. Cultural values are neither } \\
\text { right nor wrong, but just } \\
\text { different }\end{array}$ \\
\hline $\begin{array}{l}\text { 7. Understanding others' } \\
\text { situation, feelings, and motives }\end{array}$ & $\begin{array}{l}\text { 7. When in Rome, do as the } \\
\text { Romans do }\end{array}$ & $\begin{array}{l}\text { 7. When in Rome, do as the } \\
\text { Romans do }\end{array}$ & $\begin{array}{l}\text { 7. When in Rome, do as the } \\
\text { Romans do }\end{array}$ \\
\hline $\begin{array}{l}\text { 8. Understanding the value of } \\
\text { cultural diversity }\end{array}$ & $\begin{array}{l}\text { 8. Cultural awareness and } \\
\text { respect for other cultures }\end{array}$ & $\begin{array}{l}\text { 8. Cultural awareness and } \\
\text { respect for other cultures }\end{array}$ & $\begin{array}{l}\text { 8. Cultural awareness and } \\
\text { respect for other cultures }\end{array}$ \\
\hline $\begin{array}{l}\text { 9. Understanding of the role and } \\
\text { impact of culture and the impact } \\
\text { of situational, social, and } \\
\text { historical contexts involved }\end{array}$ & $\begin{array}{l}\text { 9. Satisfaction of ICC teaching } \\
\text { and learning }\end{array}$ & $\begin{array}{l}\text { 9. Satisfaction of } \\
\text { teaching and learning }{ }^{*}\end{array}$ & $\begin{array}{l}\text { 9. A great aid of ICC by the } \\
\text { Internet }\end{array}$ \\
\hline 10. Cross-cultural awareness & $\begin{array}{l}\text { 10. A great aid of ICC by the } \\
\text { Internet }\end{array}$ & $\begin{array}{l}\text { 10. A great aid of ICC by the } \\
\text { Internet }\end{array}$ & $\begin{array}{l}\text { 10. Ability to adjust to } \\
\text { international working } \\
\text { environment once in work }\end{array}$ \\
\hline $\begin{array}{l}\text { 11. Ability to adapt to different } \\
\text { communication and learning } \\
\text { styles }\end{array}$ & $\begin{array}{l}\text { 11. Ability to adjust to } \\
\text { international } \\
\text { environment once in work }\end{array}$ & $\begin{array}{l}\text { 11. Ability to adjust to } \\
\text { international } \\
\text { environment once in work }\end{array}$ & \\
\hline 12. Flexibility & $\begin{array}{l}\text { 12. Understanding others' } \\
\text { situation, feelings, and motives }\end{array}$ & & \\
\hline
\end{tabular}

Note. ${ }^{*}$ : Represents items developed in the current study. 
Twenty-four in-depth interviews were conducted from January to March 2014 to collect empirical data in China. In the first round of interviews, 12 graduates who have just graduated from China's hospitality schools were invited to participate. The second round of interviews includes six hospitality educators and six hospitality employers in China. All interviewees can be considered to be rather neutral and unbiased in the issues. The guideline for both rounds of interviews is shown in Table 2. It started with an open-ended question following the interview guide, and all interviewees were asked to discuss ICC and their perceptions of ICC. The open-ended question generated a list of 12 items (see Table 1 (b)). Then, the 12 initial items based on the literature review were provided and explained to the interviewees.

Table 2

Interview Guide

Question

Q1: How to interpret ICC in hospitality industry?

Q2: To what extent has the ICC engaged hospitality students?

Q3: Why ICC is important for hospitality students?

Q4: What suggestions do you expect the hotel school to do in terms of ICC?

The data analysis was conducted according to the content analysis method. The process of using content analysis for this study, to a large extent, followed the procedures suggested by Berg (2004). The basic steps are: (1) collect data and make it into text; (2) code the data; (3) transform codes into categories, labels, or themes; (4) sorted materials are used to collect data by categories, identifying similar phrases, patterns, relationships, and commonalities or disparities; (5) sorted materials are examined to identify and isolate meaningful patterns and processes; and (6) identified patterns are considered in the context of previous research and theories. After coding and analyzing, the researchers reduced the surplus items by combining a few items together since they shared identical meaning. For example, the items "understanding others' worldviews" and "understanding the value of cultural diversity" were combined and renamed as "understanding of other cultural values". The items "deep knowledge and understanding of culture (one's own and others')" and "culture-specific knowledge and understanding host culture's traditions" were combined and renamed as "understanding other cultures helps understand one's own better". The items "cross-cultural awareness", "open attitude towards cross-cultural learning and to people from other cultures", and "respect for other cultures" were combined and renamed as "cultural awareness and respect for other cultures". The item "flexibility" was consolidated with "when in Rome, do as the Romans do". Finally, the literature review and in-depth interviews generated a total of 11 ICC items (see Table $1(\mathrm{c})$ ).

Then, six academic experts and six hospitality employers were invited to review the content validity of these initial items in order to make ICC applicable to hotel schools in the Chinese Mainland. Using expert sampling for the initial generation of items is one of the main methods of content validation (Haynes, Richard, \& Kubany, 1995). Subsequently, they were asked to rate each of the 11 items on a 7-point Likert scale ranging from "extremely unrepresentative" to "extremely representative" to identify the extent of ICC-engaged hospitality schools. If an item's mean value is higher than 4, then this item is selected to represent ICC in hotel schools in Mainland China. Altogether, 10 out of 12 items were selected (see Table 1 (d)). The results showed that not all of the western ICCs were adopted in China. The interviewees also generated several ICC items unique to China. They were: learning and acquiring other cultural values threaten one's own identity; cultural 
values are neither right nor wrong, but just different; a great aid of ICC by the Internet; importance of ICC for hospitality students and their career; and language competency. Based on the findings of the in-depth interviews, a total of 10 items were found to represent ICC in hotel schools in China.

Descriptive statistics and one-way ANOVA with a post-hoc Scheffe test were used to assess what ICCs are important to graduates in their career development. In order to avoid bias and obtain comprehensive data collection, this study chose six hotels in cities located in north, east, southwest, and south of China in May 2014. A total of 250 questionnaires were distributed to hotel employees who graduated from hotel schools, with 200 valid questionnaires being returned, representing a response rate of $80 \%$. The graduates were asked to provide their perceptions about each of the 10 statements concerning ICC on a 7-point Likert scale, with 1 representing "completely disagree" and 7 representing "completely agree". The Chinese questionnaire was edited and proofread by two researchers, who are both proficient in English and Chinese, to ensure the accuracy of the items translated from English. The software SPSS 18 was used for the main study data analysis. The descriptive statistics of the ICC were shown in Table 3. Among the means of the 10 items, the highest mean value was "importance of ICC for hospitality students in their career" (6.58), followed by "language competency" (6.36), "understanding of and respect for other cultural values" (6.26), and "ability to adjust to international working environment once in work" (6.23), indicating that these items are the most representative items of the stakeholders' perceptions towards ICC in hospitality higher education. The lowest mean value was "learning and acquiring other cultural values threaten one's own identity" (2.87). It seems that the graduates do not think that learning other cultural values will pose a threat to their own cultures.

Table 3

Descriptive Statistics of the ICC $(N=200)$

\begin{tabular}{|c|c|c|c|c|}
\hline ICC item & Min. & Max. & Mean & Std. dev. \\
\hline 1. Importance of ICC for hospitality students in their career ${ }^{*}$ & 4 & 7 & 6.58 & 0.744 \\
\hline 2. Language competency ${ }^{*}$ & 3 & 7 & 6.36 & 0.884 \\
\hline 3. Understanding of and respect for other cultural values & 2 & 7 & 6.26 & 0.965 \\
\hline 4. Understanding other cultures helps understand one's own better & 1 & 7 & 5.58 & 1.296 \\
\hline 5. Learning and acquiring other cultural values threaten one's own identity ${ }^{*}$ & 1 & 7 & 2.87 & 1.435 \\
\hline 6. Cultural values are neither right nor wrong, but just different ${ }^{*}$ & 1 & 7 & 4.79 & 1.546 \\
\hline 7. When in Rome, do as the Romans do & 1 & 7 & 5.45 & 1.350 \\
\hline 8. Cultural awareness and respect for other cultures & 3 & 7 & 5.97 & 0.987 \\
\hline 9. A great aid of ICC by the Internet ${ }^{*}$ & 1 & 7 & 5.36 & 1.285 \\
\hline 10. Ability to adjust to international working environment once in work & 3 & 7 & 6.23 & 1.041 \\
\hline
\end{tabular}

Note. ${ }^{*}$ : Represents items developed in the current study.

\section{Results and Discussion}

Of the 200 valid questionnaires, $43.1 \%$ were completed by males and $56.9 \%$ were completed by females. The largest age group was 22 - to 24 -year-olds, accounting for $46.7 \%$ of the sample, followed by 25 - to 27 -year-olds $(34.2 \%), 19$ - to 21 -year-olds $(17.3 \%)$, and under 19 years old $(1.8 \%)$. In terms of education, $48.7 \%$ of the hotel employees had college diplomas, $35.6 \%$ had bachelor's degrees, and another $15.7 \%$ had graduated from vocational/technical schools. Finally, $62.4 \%$ interviewees were from 5 -star hotels, $28.7 \%$ from 4 -star hotels, $6.7 \%$ from 3-star hotels, and 2.2\% from 2-star hotels. One-way ANOVA with a post-hoc Scheffe test was adopted to examine the difference between different ICC on graduates' career 
development. Out of the nine dependent variables, significant differences were observed on five variables with various levels of significance. The five variables were: language competency; understanding other cultures helps understand one's own better; cultural awareness and respect for other cultures; a great aid of ICC by the Internet; and ability to adjust to international working environment once in work (see Table 4).

Table 4

Results of ANOVA Analysis

\begin{tabular}{llll}
\hline Dependent variable & df & $F$ & Sig. \\
\hline Language competency & 3 & 6.673 & $0.000^{* *}$ \\
Understanding of and respect for other cultural values & 3 & 2.244 & 0.087 \\
Understanding other cultures helps understand one's own better & 3 & 4.123 & $0.008^{*}$ \\
Learning and acquiring other cultural values threaten one's own identity & 3 & 0.826 & 0.482 \\
Cultural values are neither right nor wrong, but just different & 3 & 0.241 & 0.867 \\
When in Rome, do as the Romans do & 3 & 0.049 & 0.985 \\
Cultural awareness and respect for other cultures & 3 & 4.336 & $0.006^{*}$ \\
A great aid of ICC by the Internet & 3 & 4.347 & $0.006^{*}$ \\
Ability to adjust to international working environment once in work & 3 & 12.502 & $0.000^{* *}$ \\
\hline
\end{tabular}

Note. ${ }^{*}$ : The mean difference is significant at the $5 \%$ level; ${ }^{* *}:$ The mean difference is significant at the $1 \%$ level.

Based on the descriptive statistics analysis, it is found that the respondents are fully aware of the importance of ICC with the highest mean value of 6.58 . Working within the hospitality industry, as well as understanding the social and cultural aspects of tourism, requires employees to be aware of the challenges that often arise between customers of different languages and members of different cultures. As shown in Table 4, for the "language competency" item, the one-way ANOVA determines the significant difference at the $p \leq 0.000$ $(F=6.673, p=0.000)$ with the mean value of 6.36. In the increasingly international and mobile China, knowledge of foreign languages plays an important and sometimes a decisive role in the employability of graduates in the hospitality industry. In the process of learning a new language, it is important to be aware of its cultural aspect(s), because the knowledge of other cultures helps a learner to learn a certain language and to assess cultural values of that language (Ellis, 2005). In order to develop ICC, students should not only learn a foreign language, but such a process should also include intercultural training and intercultural exchange of ideas. It is evident that the knowledge and the competence acquired in this learning process will highly contribute to the development of tourism and hospitality services in general.

For the "understanding other cultures helps understand one's own better" item, one-way ANOVA demonstrates the significant difference at the $p<0.05(F=4.123, p=0.008)$ with the mean value of 5.58. The cross-cultural experience should help the student form a clearer understanding and appreciation of the characteristics of another culture and its complexity and diversity. While developing a sense of cross-cultural acceptance, students will also gain an appreciation of the sources and values of their own culture. This indicates that students should demonstrate growth in their competence to understand and acknowledge cultural differences and to conceptually relate one's own culture to another. For the "cultural awareness and respect for other cultures" item, one-way ANOVA reveals the significant difference at the $p<0.05(F=4.336, p=0.006)$ with the mean value of 5.97. International visitors on leisure and business trips often expect service providers to understand their values and cultural beliefs by exhibiting a certain level of ICC (Katriel, 1995). The growth and very existence of companies in these industries will become more dependent on the success of these encounters 
between employees and foreign guests (Bhawuk, 2001). It means that graduates must know how their Chinese values may differ from those from other cultures which they should respect. Graduates looking for a career in hospitality industry must develop this competence and achieve successful interactions with customers from other cultures.

For the "a great aid of ICC by the Internet" item, one-way ANOVA indicates the significant difference at the $p<0.05(F=4.347, p=0.006)$ with the mean value of 5.36. The use of Internet technologies may offer a solution to developing language and intercultural skills in countries like China where face-to-face experiential learning is difficult. Shi (2006) reported that a web-based intercultural training program was valuable in helping learners enhance their ICC. Hospitality educators and learners are broadly enthusiastic and supportive of developing ICC by incorporating Internet technologies into traditional classroom instructions (Wang \& Coleman, 2009). Nowadays, the Internet is playing an important role in the hospitality and tourism industry. By the use of the Internet, students are given an opportunity to learn different cultures and respect people from other cultures. Thus, acquiring the knowledge and understanding of cultural factors is the key to successful communication across cultures (Beamer, 1992). As for the "ability to adjust to international working environment once in work" item, one-way ANOVA indicates the significant difference at the $p \leq 0.000$ $(F=12.502, p=0.000)$ with the mean value of 6.23. Working adjustment involves adapting oneself to the new environment with unfamiliar surroundings and cultures. Working in a culturally different environment is always a challenge, so it is not surprising that the lack of cultural knowledge and language ability and a difficulty in adjusting to the culture difference are major factors affecting career development (Dowling \& Welch, 2005). The hospitality and tourism industry is a labor-intensive industry which demands high levels of contact between their stakeholders. The ICC is a core competence for graduates in the industry to perform their various tasks professionally and effectively. The participants know well that different cultures should be respected and hospitality professionals should continue to improve their ICC throughout their careers which were consistent with those of previous studies (Lustig \& Koester, 2006; Martin \& Nakayama, 2007). The results revealed can be referred to as a starting point for the educators to consider integrating more cultural ingredients in hospitality studies.

In-depth interview was employed to explore the stakeholders' perceptions in this study and more discussions are also as follows. A few of interviewees are more concerned with the "invasion" of other cultural values whilst the majority of participants are not. Judging from the context, it seems that the educators might feel it more urgent to protect and promote traditional Chinese cultural values than introducing western values. They might be anxious that globalization has negatively impacted the Chinese culture, which should stand out in the world. Interestingly, however, most of graduates are confident that traditional Chinese values will not be easily replaced under foreign influences. Learning other cultures will help one understand and better promote one's own culture, particularly in the case of a country like China which has a rich cultural history. Furthermore, two hotel employers remark that China has been open to the world for decades and now "we are rather unshockable about foreign cultures".

The majority of interviewees admit that the students need to improve their linguistic skills first. Learning cultures involves deeper understanding and fluency in the target language. Otherwise, it would be impossible for the graduates to mediate among different cultures. Superficial greetings will prove inadequate in intercultural communication. From the in-depth interview, two educators state that linguistically, the students can only exchange greetings with their teachers and vocabulary gets in the way when they try to communicate 
with people from different cultures. Some graduates argue that language classes seem to be dominated by linguistic training and subjects concerning ICC are separated from language course. All interviewees agree that international teachers could be better at teaching cultures whilst the domestic bilingual staff better at enhancing the students' linguistic skills. Apart from improving language skills, one employer indicates that employees have to learn more about current affairs and broaden their vision.

The importance of ICC for hospitality students in their career is well recognized by the interviewees. Due to their limited exposure to direct face-to-face contact with people from other cultures, online chatting is one of the most common ways to improve their linguistic skills and understanding of foreign cultures. One graduate admitted that she felt excited yet nervous when chatting in English with people from different cultures via the Internet. Apart from emphasizing the Internet as an aid to teaching ICC, One employer encourages that more experiential leaning should be involved in hospitality higher education related to ICC. Another declares that cultural awareness would be best to be developed at hospitality higher education. Most of the employers agree that ICC will be of great help for career development in hospitality. However, they disclose that most of the colleges' present curriculum can hardly meet industry demands. They suggest that colleges need to keep on updating the curriculum by listening to industry voices. Some graduates acknowledge the fact that in the $21 \mathrm{st}$ century, China's opening will bring along opportunities for tourism graduates to go and work abroad. ICC will help them know more about others. In their future careers, ICC will be useful to express themselves more "freely and exactly".

\section{Conclusion and Recommendations}

This study explores the stakeholders' perceptions towards ICC in hospitality higher education in China and what ICCs are important to graduates in their career development. All the stakeholders have agreed upon the importance of ICC for hospitality graduates in their career. Most graduates hope for integration of ICC with bilingual languages teaching and prefer experiential learning related to ICC. Language teaching or learning should not be separated from ICC acquiring and the use of the Internet is encouraged to aid classroom teaching. The appeal from employers to update ICC teaching content is well worth noting. Thus, introducing different cultural values will not jeopardize the learners' identification with their home cultures. The integration of ICC with language teaching is a necessity to capture the students' interest and prepare future professionals for the industry. Yet, what and how to integrate ICC would demand more investigation and exploration. Based on the results of the study, recommendations are as follows.

Language teaching or learning should not be separated from ICC acquiring. It is recommended that an academic institution could think about training the educators and operate student exchange programs/student internship abroad. It would be best to send the bilingual staff to study abroad for a period of time in order to gain a deeper understanding of cultures in the target language. Bilingual teachers who know both cultures better than the monolingual educators might be efficient in teaching ICC to the students. International exchanges programs or student internship in other counties will enable the students to learn about different cultures as well. Though the learners might not be perfect in language skills, they should be given the opportunity to explore aspects of both home and target cultures with sensitivity and respect (Corbett, 2003) by enhancing their ability to adjust to the international environment. Moreover, it would be a good practice for tourism or hotel organizations to continue to offer culture-oriented training programs to the students from schools and colleges. In-house ICC training at those organizations could be more tailor-made and better adapted to meet the demands from work. 
It is recommended that academic institution may gather the stakeholders to decide upon restructuring the curriculum of hospitality management courses and ICC teaching, if necessary. When developing a new ICC curriculum, the scope of content could be extended to include non-English-speaking markets, such as Muslim, Arabic, Russian, or Spanish-speaking societies. This recommendation would be helpful in developing a more integrated curriculum for ICC learning. Curricular internationalization is expected to result in preparing future professionals with strong ICC. More research in the intercultural impacts to facilitate curricular internationalization would benefit the stakeholders in the hospitality industry in China.

This study could be of major use to hospitality undergraduates, educators, and employers in the Chinese Mainland. From graduates' perspective, the study may help them improve their ICC learning at schools for better advancement in their future careers. From educators' perspective, it may provide a better understanding from the stakeholders' perceptions when integrating cultural elements with communicative competence in hospitality education, and prepare qualified students. From employers' perspective, ICC can be a valuable tool when recruiting quality graduates. In addition, a greater understanding of ICC contributes to graduates' career development, universities' curriculum validation, and service quality in hospitality industry.

\section{Limitations}

Due to the small research scale of this study, the 10 ICC items developed in the study rest mostly on qualitative research work and there is not yet sufficient empirical evidence to support the result. There is a need for future study to empirically test the validity and reliability of the ICC developed.

\section{References}

Aliouche, E. H., \& Schlentrich, U. (2011). A model of optimal international market expansion: The case of US hotel chains expansion into China. New Developments in the Theory of Networks, 1, 135-154.

Beamer, L. (1992). Learning intercultural communication competence. International Journal of Business Communication, 29(3), 285-303.

Berg, B. L. (2004). Qualitative research methods for the social sciences (5th ed.). Toronto: Pearson.

Bhawuk, D. P. S. (2001). Evolution of culture assimilators: Toward theory-based assimilators. International Journal of Intercultural Relations, 25(2), 141-163.

Chen, G. M., \& Starosta, W. J. (1996). Intercultural communication competence: A synthesis. In R. B. Brant (Ed.), Communication yearbook 19. Thousand Oaks, CA: Sage Publications.

Chen, S. (2001). Strategic study of language and culture teaching. Beijing: Beijing Language and Culture University Press.

Collier, M. J. (1989). Cultural and intercultural communication competence: Current approaches and directions for future research. International Journal of Intercultural Relations, 13(3), 287-302.

Corbett, J. (2003). An intercultural approach to English language teaching. Clevedon, Sydney: Multilingual Matters, Ltd..

Cushner, K. H., \& Brislin, R. W. (1996). Intercultural interactions: A practical guide. Thousand Oaks, CA: Sage Publications.

Deardorff, D. K. (2006). Identification and assessment of intercultural competence as a student outcome of internationalization. Journal of Studies in International Education, 10(3), 241-266.

Dowling, P., \& Welch, D. (2005). International human resource management: Managing people in a multinational context (4th ed.). Mason, $\mathrm{OH}$ : South-Western.

Educational Ministry of China. (2004). College English curriculum requirements (for trial implementation). Shanghai: Shanghai Foreign Language Education Press.

Ellis, R. (2005). Principles of instructed language learning. System, 33(2), 209-224.

Ferraro, G. P. (2006). The cultural dimensions of international business. Upper Saddle River, NJ: Pearson Prentice Hall.

$\mathrm{Gu}$, J. (Ed.). (2000). Cross-cultural communication: Hidden dimension in foreign language and literature. Nanjing: Nanjing Normal University Publishing House. 
Gu, Q. (2009). Maturity and interculturality: Chinese students' experiences in UK higher education. European Journal of Education, 44(1), 37-52.

Gu, Q., \& Maley, A. (2008). Changing places: A study of Chinese students in the UK. Language and Intercultural Communication, 8(4), 224-245.

Gudykunst, W. B., \& Mody, B. (Eds.). (2002). Handbook of international and intercultural communication (2nd ed.). Thousand Oaks, CA: Sage Publications.

Gurung, G., Simmons, D., \& Devlin, P. (1996). The evolving role of tourist guides: The Nepali experience. In R. Bulter, \& T. Hinch (Eds.), Tourism and indigenous peoples (pp. 107-128). London: International Thomson Business Press.

Haynes, S. N., Richard, D. C. S., \& Kubany, E. S. (1995). Content validity in psychological assessment: A functional approach to concepts and methods. Psychological Assessment, 7(3), 238-247.

Holliday, A., Hyde, M., \& Kullman, J. (2004). Intercultural communication: An advanced resource book. London: Routledge.

Hu, W. Z., \& Gao, Y. H. (1997). Foreign language teaching and culture. Changsha, Hunan: Hunan Education Publishing House.

Katriel, T. (1995). From "context" to "contexts" in intercultural communication research. In R. L. Wiseman (Ed.), Intercultural communication theory (pp. 12-84). Thousand Oaks, CA: Sage Publication.

Kim, M. S. (1994). Cross-cultural comparisons of the perceived importance of conversational constraints. Human Communication Research, 21(1), 128-151.

Kotler, P., Bowen, J., \& Makens, J. (2003). Marketing for hospitality and tourism. Upper Saddle River, NJ: Pearson Prentice Hall.

Le Roux, J. (2002). Effective educators are culturally competent communicators. Intercultural Education, 13(1), 37-48.

Liu, R. (2000). Cross-cultural communication: Hidden dimension in foreign language and literature. J. Gu, (Ed.). Nanjing: Nanjing Normal University Publishing House.

Lustig, M. W., \& Koester, J. (2006). Intercultural competence: Interpersonal communication across cultures (5th ed.). Boston, MA: Person Education, Inc..

Martin, J. N., \& Nakayama, T. K. (2007). Intercultural communication in contexts (4th ed.). New York, NY: McGraw-Hill Companies, Inc..

National CET IV and VI Committee. (2007). CET IV curriculum. Shanghai: Shanghai Foreign Language Education Press.

Patton, M. Q. (1990). Qualitative evaluation and research methods. Thousand Oaks, CA: Sage Publications.

Saee, J. (2006). Managerial competence within the hospitality and tourism service industries: Global cultural contextual analysis. New York, NY: Routledge.

Scollon, R., \& Scollon, S. W. (2001). Intercultural communication: A discourse approach (2nd ed.). Malden, MA: Blackwell.

Shi, L. (2006). Internet-based development of cultural knowledge and awareness among Chinese students of English: Attitudes, obstacles, and potential (Unpublished Ph.D. thesis, The Open University).

Tian, J. (2013). Beliefs and practices regarding intercultural competence among Chinese teachers of English at a Chinese university (Unpublished doctoral dissertation, George Mason University, Fairfax, VC).

United Nations World Tourism Organization [UNWTO]. (2008). World tourist arrivals: From 800 million to 900 million in two years. UNWTO World Tourism Barometer, 6(1), 1-43.

Wang, L., \& Coleman, J. A. (2009). A survey of Internet-mediated intercultural foreign language education in China. ReCALL, 21(1), 113-129.

Wang, Z. (1999). The linguistic and cultural division of Englishes in English as an international language. Proceedings of China's 2nd Conference on Intercultural Communication (pp. 596-616). Beijing: Foreign Language Teaching and Research Press.

Weiler, B., \& Ham, S. H. (2001). A comparative analysis of ecotour guiding on cruise-based tours. Paper presented at the 11th Australian Tourism and Hospitality Research Conference, University of Canberra, Canberra.

Whyte, L. (1990). A national curriculum for the teaching of Asian languages and culture in hospitality programs. Journal of Hospitality and Tourism Research, 14(2), 319-326.

Zhang, A. D., \& Zhang, X. (2002). On the nurture of cultural awareness and cultural input in English teaching. Foreign Languages and Their Teaching, 6, 25-27. 